\title{
Genetic chimerism of Vitis vinifera cv. Chardonnay 96 is maintained through organogenesis but not somatic embryogenesis Christophe Bertsch ${ }^{1}$, Flore Kieffer ${ }^{1}$, Pascale Maillot ${ }^{1}$, Sibylle Farine ${ }^{1}$, Gisèle Butterlin², Didier Merdinoglu² and Bernard Walter*1
}

\author{
Address: ${ }^{1}$ Université de Haute-Alsace, Laboratoire Vigne Biotechnologies et Environnement, 33, rue de Herrlisheim 68000 Colmar, France and \\ 2INRA, UMR 1131, Vigne et Vin d'Alsace, 28, rue de Herrlisheim 68000 Colmar, France \\ Email: Christophe Bertsch - christophe.bertsch@uha.fr; Flore Kieffer - flore.kieffer@uha.fr; Pascale Maillot - pascale.maillot@uha.fr; \\ Sibylle Farine - sibylle.farine@uha.fr; Gisèle Butterlin - butterl@colmar.inra.fr; Didier Merdinoglu - merdino@colmar.inra.fr; \\ Bernard Walter* - bernard.walter@uha.fr \\ * Corresponding author
}

Published: 29 September 2005

BMC Plant Biology 2005, 5:20 doi:10.1 186/147|-2229-5-20

This article is available from: http://www.biomedcentral.com/I47/-2229/5/20

(C) 2005 Bertsch et al; licensee BioMed Central Ltd.

This is an Open Access article distributed under the terms of the Creative Commons Attribution License (http://creativecommons.org/licenses/by/2.0), which permits unrestricted use, distribution, and reproduction in any medium, provided the original work is properly cited.
Received: 25 April 2005

Accepted: 29 September 2005

\begin{abstract}
Background: Grapevine can be a periclinal chimera plant which is composed at least of two distinct cell layers (LI, L2). When the cell layers of this plant are separated by passage through somatic embryogenesis, regenerated plants could show distinct DNA profiles and a novel phenotype which proved different from that of the parent plant.

Results: Genetically Chardonnay clone 96 is a periclinal chimera plant in which is LI and L2 cell layers are distinct. Plants obtained via organogenesis through meristematic bulks are shown to be composed of both cell layers. However, plants regenerated through somatic embryogenesis starting from anthers or nodal explants are composed only of LI cells. These somaclones do not show phenotypic differences to the parental clone up to three years after regeneration. Interestingly, the only somaclone showing an atypical phenotype (asymmetric leave) shows a genotypic modification.

Conclusion: These results suggest that the phenotype of Chardonnay 96 does not result from an interaction between the two distinct cell layers LI and L2. If phenotype conformity is further confirmed, somatic embryogenesis will result in true-to-type somaclones of Chardonnay 96 and would be well suitable for gene transfer.
\end{abstract}

\section{Background}

Improvement of grapevine rootstocks and scion varieties can be achieved through either inter-specific hybridization or clonal selection. Grapevine clonal selection consists in choosing in a variety one plant presenting desired characteristics. This selected plant is further propagated by vegetative multiplication known to maintain trueness-totype. But clonal selection is restricted to the natural variability of a given cultivar, within the limits of the character- istics on which the trueness-to-type is based. Somatic embryogenesis could be an additional possibility for varietal improvement. A broader perspective of improvement of grapevine cultivars for characteristics such as resistance to pests and diseases has been opened by transgenic technologies which in most cases are based on somatic embryogenesis of grapevine [1] and shoot organogenesis [2]. One question to be addressed is the phenotypic and genotypic variability of grapevine clones raised through 
Table I: Genotypes of Chardonnay clone 96 at the VMC $5 \mathrm{g7}$ and VMC 6clo loci.

\begin{tabular}{llll}
\hline \multicolumn{3}{c}{ Locus alleles (bP) } \\
\hline DNA origin & VMC 6c10 & VMC 5g7 & cell layer \\
\hline Leaves & $114: 140: 142$ & $198: 220: 222$ & $\mathrm{LI}+\mathrm{L} 2$ \\
Wood & $114: 142$ & $198: 220$ & $\mathrm{~L} 2$ \\
Rootlets & $114: 142$ & $198: 220$ & $\mathrm{~L} 2$ \\
Berry skin & $114: 140: 142$ & $198: 220: 222$ & $\mathrm{LI}+\mathrm{L} 2$
\end{tabular}

somatic embryogenesis or shoot organogenesis. Recently, Desperriers et al. [3] presented results of a ten years observation of Vitis vinifera Gamay somaclones which showed variations in fertility as well as sugar content, size and level of maturity of the grapes. These observations illustrate that somaclones can differ from the original parent without changing the fundamental typicity of the wine. One possible origin of variability may be the separation of cell layers of the mother plant from which clones are grown.

The grapevine meristem is considered to be composed at least of two distinct cell layers L1 and L2 [4], which can produce a chimeric tissue structure. For example, Vitis vinifera $\mathrm{cv}$. Pinot Meunier phenotype is due to the interaction of genetically distinct cell layers. When the cell layers of Pinot Meunier periclinal chimera were separated by passage through somatic embryogenesis, regenerated plants showed distinct DNA profiles which proved to be different from that of the parent plant. Regenerated somaclones also showed a novel phenotype [5].

About five hundred microsatellite markers of the grapevine genome are now available and widely as well as very efficiently used for identification of cultivars [6-8]. Riaz et al. [9] used microsatellite markers for the detection of reproducible intra-cultivar polymorphism in Vitis vinifera Chardonnay and Pinot noir. Furthermore, some of these microsatellite markers made it possible to differentiate the two cell layers L1 and L2 in some clones of both cultivars $[9,10]$.

A previous paper [11], showed that in the leaf tissue of Chardonnay 96 the microsatellite marker VMC $5 \mathrm{~g} 7$ revealed two standard alleles (198:220 bp) and a variant allele (222 bp) previously defined by Riaz et al. [9]. Wood tissues and roots only presented the two standard alleles with VMC 5g7. With a second microsatellite marker (VMC 6g10), two standard alleles (114:140 bp) and a mutant allele (142 bp) were detected in leaves. This mutant allele replaced one of the standard alleles in woods and roots
(114:142 bp). In addition, we showed, that somaclones regenerated from anthers of a single inflorescence all derived from L1 cells exclusively.

In the present paper we report results of a wider genotypic analysis of somaclones regenerated either from anthers of different inflorescences or from nodal explants of Chardonnay 96. The same microsatellite markers were also used to compare the genotype of different clones obtained through shoot organogenesis. The genotypic identities (L1; L2) of the regenerated clones are in accordance with their respective phenotypic characteristics.

\section{Results \\ Genotypic analysis of various tissues of Chardonnay 96 mother clone}

Three alleles were detected in leaves of Chardonnay 96 mother clone with the microsatellite marker VMC $6 \mathrm{c} 10$ : the $114 \mathrm{bp}$ and $140 \mathrm{bp}$ standard alleles and an additional 142 bp variant allele (table 1 ). The standard alleles were defined by Riaz et al. [9] as the most frequently detected alleles in different clones of the same cultivar. VMC $5 \mathrm{~g} 7$ revealed in leaves the two $198 \mathrm{bp}$ and 220 bp standard alleles and a 222 bp variant allele (table 1). The same genotype was observed with leaves from in vitro or greenhouse-grown plants. In the DNA extracted from rootlets and wood tissues, only the two pairs of alleles 114:142 and 198:220 were detected with VMC 6c10 and VMC 5g7 respectively (table 1 ). In berry skin, the triallelic profiles were detected with both markers. It is known that wood and roots are composed of L2 cells only and that leaves comprise L1 and L2 cell layers. Our results lead to the conclusion that the VMC 6c10 $114 \mathrm{bp}$ and $142 \mathrm{bp}$ alleles as well as the VMC 5g7 $198 \mathrm{bp}$ and $220 \mathrm{bp}$ alleles are present in L2 cells of Chardonnay 96. We can also deduce that L1 cells have the VMC 6c10 $114 \mathrm{bp}$ and $140 \mathrm{bp}$ alleles and the VMC $5 \mathrm{~g} 7$ the $198 \mathrm{bp}$ and $222 \mathrm{bp}$ alleles.

\section{Regeneration of plants through somatic embryogenesis or shoot organogenesis}

Four different inflorescences of Chardonnay 96 were used to collect anthers. Primary somatic embryos were obtained from anther-derived embryogenic calli after a 2 month period (figure 1A). Secondary embryos were obtained 1 month after initiation of embryogenic calli from primary embryos. Embryogenic calli and primary embryos from nodal explants were obtained after 2-4 months (figure 1B). Meristematic bulks developed after successive transfers of shoots on IM medium with benzyladenine concentrations increasing up to $13.2 \mu \mathrm{M}$. High numbers of adventitious shoots regenerated from slices cut from the meristematic bulk tissues, and rooted plantlets further developed (figure 1C). 
A)
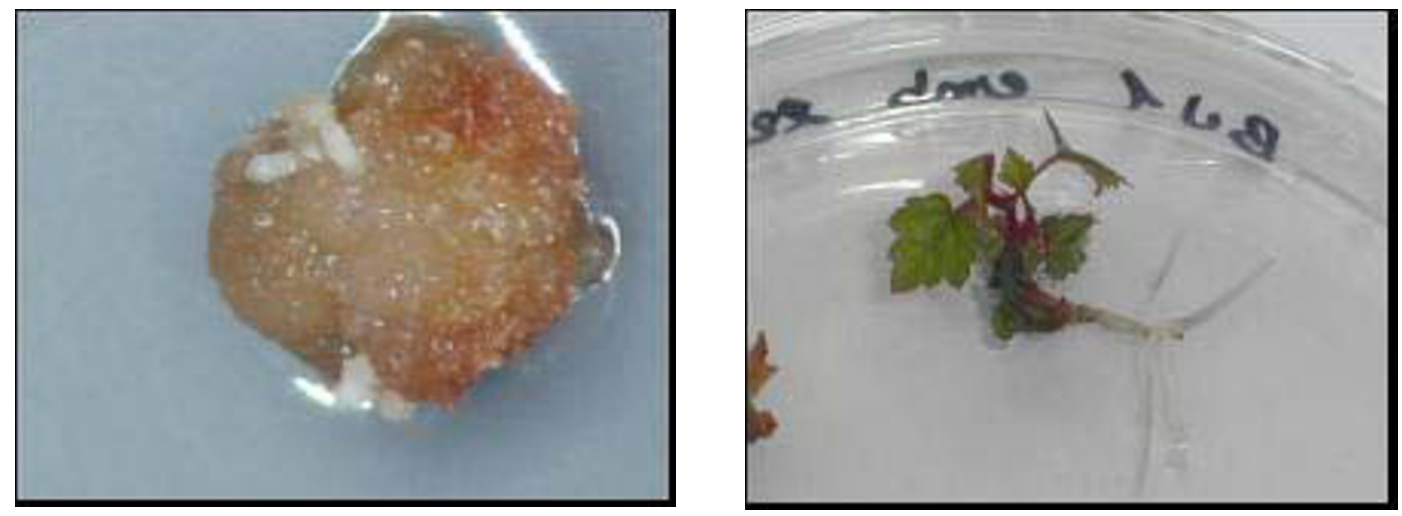

B)
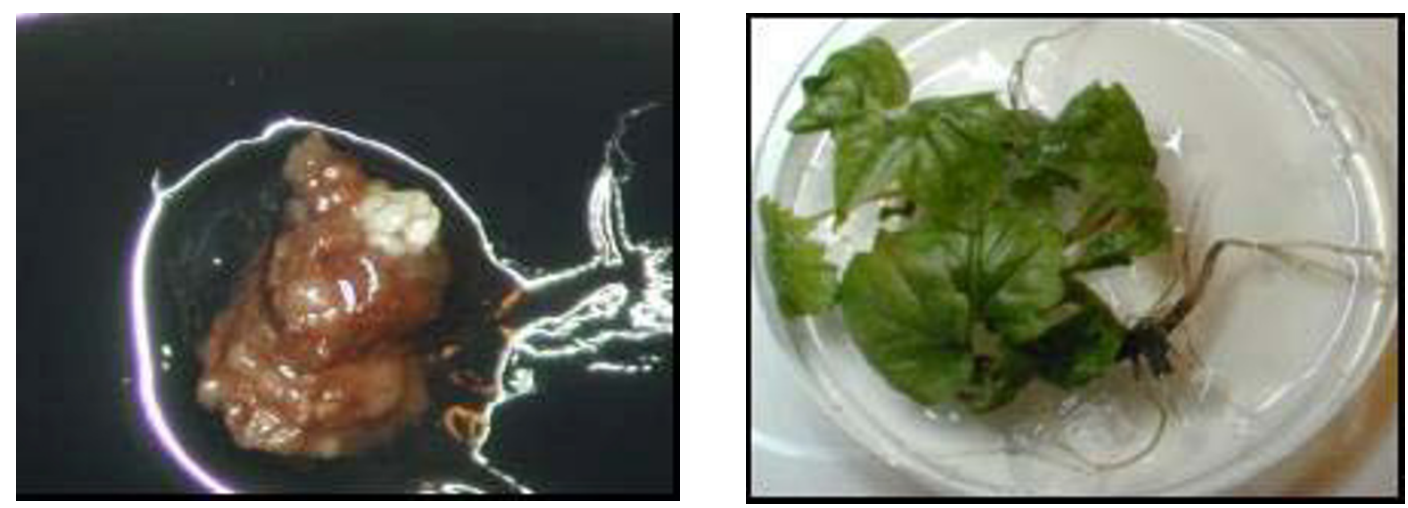

C)

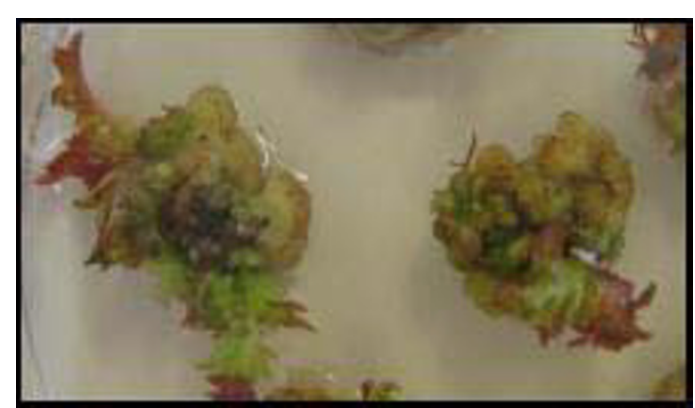

Figure I

Somatic embryogenesis and shoot organogenesis of Vitis vinifera Chardonnay 96. A) Embryogenic callus from anthers and plant regeneration, B) Embryogenic callus from nodal explants and plant regeneration, C) Shoot organogenesis from meristematic bulk.

Efficient plant growth was further obtained with a number of somaclones. The plants did not show any atypical phenotype in visual comparison with vegetatively propagated Chardonnay 96 grown in the growth chamber and the greenhouse. Except one somaclone $\left(\mathrm{n}^{\circ} 21\right)$ originated from an anther-derived callus. 
Table 2: Genotypes at the VMC $5 g 7$ and VMC $6 \mathrm{cl} 0$ loci of clones regenerated through embryogenesisor shoot organogenesis

\begin{tabular}{|c|c|c|c|c|}
\hline \multirow[b]{2}{*}{ Plant origin } & \multicolumn{4}{|c|}{ Locus alleles (bp) } \\
\hline & DNA origin & $\mathrm{VMC} 6 \mathrm{cl} 10$ & VMC 5g7 & cell layer of origin \\
\hline \multicolumn{5}{|l|}{ anthers } \\
\hline \multicolumn{5}{|l|}{ Inflorescence $A$} \\
\hline \multirow{2}{*}{ Primary $(20)$ or secondary (6) somaclones } & Leaves iv $+g h$ & || $4: 140$ & $198: 222$ & LI \\
\hline & Rootlets iv & $1 \mid 4: 140$ & 198:222 & LI \\
\hline \multicolumn{5}{|l|}{ Inflorescence B } \\
\hline Primary somaclones (3) & Leaves iv & $1 \mid 4: 140$ & 198:222 & LI \\
\hline \multicolumn{5}{|l|}{ Inflorescence $C$} \\
\hline Primary (5) or secondary (I) somaclones & Leaves iv $+g h$ & $1 \mid 4: 140$ & 198:222 & LI \\
\hline \multicolumn{5}{|l|}{ Inflorescence D } \\
\hline Primary somaclone (I) & Leaves iv $+g h$ & $\mid 14: 140$ & 198:222 & LI \\
\hline \multicolumn{5}{|l|}{ nodal explants } \\
\hline \multicolumn{5}{|l|}{ Primary somaclones (16) } \\
\hline & Leaves iv & || $4: 140$ & 198:222 & LI \\
\hline & Rootlets iv & $\mid 14: 140$ & 198:222 & LI \\
\hline \multicolumn{5}{|l|}{$\begin{array}{l}\text { meristematic bulk } \\
\text { clones (7) }\end{array}$} \\
\hline & Leaves iv & II4:140:142 & 198:220:222 & $\mathrm{LI}+\mathrm{L} 2$ \\
\hline
\end{tabular}

\section{from:}

- anthers from 4 different inflorescences (A, B, C, D)

- nodal explants

or through shoot organogenesis from meristematic bulks

$\left(\mathrm{N}^{\circ}\right)$ : number of clones, iv : in vitro, gh : greenhouse

\section{Genotypic analysis of Chardonnay 96 somaclones obtained from anthers and from nodal explants}

The same genotypic profiles were obtained with a total of 29 primary and 7 secondary somaclones regenerated from anthers collected from 4 different inflorescences and 16 clones from nodal explants (table 2). In leaves from in vitro and greenhouse-grown plants, the standard genotype (114:140) was visualised with VMC 6c10. For VMC $5 g 7$ in addition to the standard 198 bp allele, the 222 bp variant allele was detected in leaves from all somaclones (table 2). In the rootlets, the standard diallelic genotype was visualised with VMC 6c10. With VMC $5 g 7$ the 198 bp standard allele and the 222 bp variant allele were detected (table 2). These results show that all somaclones regenerated from L1 cells of the Chardonnay 96 explants.

\section{Phenotypic and genotypic analysis of somaclone $n^{\circ} 21$}

Compared to the Chardonnay 96 mother clone, which presents mature circular leaves undivided or with five lobes, all leaves from somaclone $n^{\circ} 21$ show one circular undivided half and the other half with separated lobes (figure 2). This phenotype was observed after the acclima- tization and is still observed after 3 years on greenhousegrown plants only for this somaclone.

In leaves from in vitro and greenhouse-grown somaclone 21 , the triallelic profile was detected with VMC 6c10. For VMC $5 \mathrm{~g} 7$ in addition to the standard 198 bp allele, the 222 bp variant allele was detected. The same results were obtained with berry skin. In the rootlets, the standard allele (114) and the mutant allele (142) were visualised with VMC 6c10 and with VMC 5g7 the standard allele (198) and the mutant allele (222) were detected (table 3). These results indicate that the genotype of somaclone 21 is the same as that of the mother clone for VMC $6 \mathrm{c} 10$, but for VMC $5 \mathrm{~g} 7$ only 2 alleles present in the L1 cell layer of the mother plant are present. A mutation in the microsatellite sequence VMC $6 \mathrm{c} 10$ from the L1 cell type of the mother clone probably occurred during embryogenesis of clone 21 .

\section{Genotypic analysis of clones obtained through shoot organogenesis}

Leaves from all 7 clones obtained through shoot organogenesis show the triallelic profile both for VMC 6c10 and 


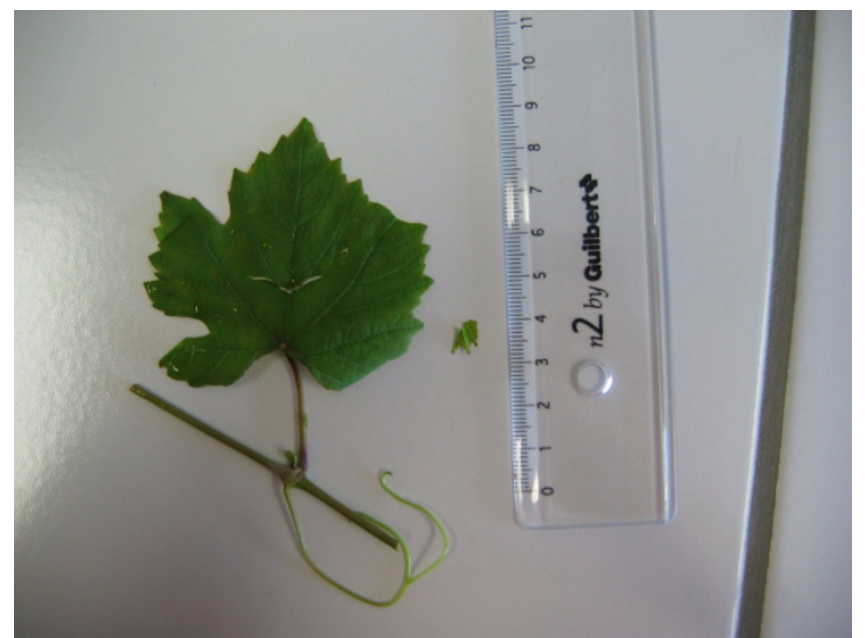

Figure 2

Asymmetric leaf of a 3 year-old atypical somaclone $n^{\circ} 21$ plant.

Table 3: Genotype of the somaclone 21 at the VMC 5g7 and VMC 6cl 0 loci

\begin{tabular}{lll}
\hline & \multicolumn{2}{l}{ Locus alleles (bp) } \\
\hline DNA origin & VMC 6c10 & VMC 5g7 \\
\hline Leaves & $114: 140: 142$ & $198: 222$ \\
Rootlets & $114: 142$ & $198: 222$ \\
Berry skin & $114: 140: 142$ & $198: 222$ \\
\hline
\end{tabular}

VMC 5g7 (table 2). This suggests that plants obtained via organogenesis through meristematic bulks are derived from both L1 and L2 cell layers of the Chardonnay 96 tissues from which they grew.

\section{Discussion}

Vitis vinifera Chardonnay clone 96 is a periclinal chimera In grapevine, apical meristems are composed of two or more cell layers forming the tunica in addition to a corpus $[4,12]$. In the leaf tissue from Chardonnay 96, which is derived from both the outer tunica layer $\mathrm{L} 1$ and the inner cell layer L2, the microsatellite marker VMC 5g7 revealed the two standard alleles and a variant allele previously defined by Riaz et al. [9]. Wood tissues and roots, which originate exclusively from the L2 layer, presented only the two standard alleles. The presence of a third allele in leaf suggests that Chardonnay is a periclinal chimera in which a mutant allele is present only in the L1 layer, as described by Riaz et al. [9]. For the microsatellite marker VMC 6g10, a mutant allele was detected in leaves, wood tissue and roots. This mutant allele replaced one of the standard alleles in woods and roots, whereas in leaves the mutant allele was present simultaneously with the two standard alleles [11]. These results suggest that the 2 bp-mutation resulting in the replacement of the VMC 6c10 $140 \mathrm{bp}$ allele by the 142 bp allele only occurred in L2. Riaz et al. [9] propose that the mutation most likely occurred in an L1 or L2 cell and then came to populate both layers of the meristem rather than two identical mutations appearing independently in the L1 and L2. Results reported by Riaz et al. [9] were based on visual interpretation of electrophoretic profiles of amplification products. We suggest that such observations could be biased by the DNA polymerase slippage. Our analyses with ABI PRISM allowed to differentiate between an allele and the different stutter bands, without ambiguity.

\section{Somaclones develope only from LI cells of Chardonnay 96} In the present study, we show that somaclones obtained not only from anthers from different inflorescences but also from nodal explants all derived from L1 cells. Embryogenic calli were composed exclusively of cells showing the genetic profile of L1 cells of the mother clone Chardonnay 96 (data not shown), suggesting that L2 cells could not multiply into callus at least in our culture conditions. On another hand, clones raised through shoot organogenesis are composed of cells showing the genetic profiles of both L1 and L2 cells of the mother clone. These observations suggest that the genetic chimerism of Chardonnay 96 is maintained through shoot organogenesis but not through somatic embryogenesis.

Anthers are the most widely used organ for initiation of grapevine somatic embryos. It has been shown that embryogenic cells derive from the anther filament. Both L1 and L2 cell layers seem to be competent to form embryogenic calli in some conditions, as reported for Pinot Meunier by Franks et al. [9]. Filaments from anthers of Chardonnay 96 are composed of L1 and L2 cells (data not shown). But, in our conditions only L1 cells of Chardonnay 96 developed into embryos. A similar result was reported recently with Pinot gris from which only the L1 cell layer is competent to form embryogenic callus [10].

\section{Phenotype variation of Chardonnay $\mathbf{9 6}$ somaclones}

Embryogenesis might generate new grapevine phenotypes when the mother plant is a chimera of genetically distinct cell layers. For example, the separation of chimeric cell layers of Pinot Meunier through somatic embryogenesis generated plants that had distinct DNA profiles and had novel phenotypes which were different from those of the parent plants [5]. The phenotype of all the somaclones we obtained from anthers has been observed for 2-3 years in a glasshouse: no visible modification was noticed (except 
for the somaclone $\mathrm{n}^{\circ} 21$ ) in comparison to the mother clone Chardonnay 96. This phenotypic conformity suggests that the L2 genotype would not significantly participate in the phenotypic expression in the L1-L2 chimeric Chardonnay 96. More subtle variations in fruit setting and wine quality may be only detected in the future, when the somaclones will be grown in the vineyard. Variation of colour intensity, sugar content, size and level of maturity of the grapes has been reported for adult somaclones of Gamay after ten years observation [3]. Though no genotypic analyses were done for the different Gamay somaclones, it can be hypothesised that this somaclonal variation is of epigenetic origin [13]. The Chardonnay 96 mother clone shows the typical ampelographic traits of the cultivar Chardonnay with mature circular leaves undivided or with five lobes, petiolar sinus slightly open, often limited through veins at petiole end. Some adult leaves of somaclone 21 have an asymmetric shape, one half undivided or slightly lobed, the other half deeply lobed. Somaclone 21 probably arose from L1 cell(s) of Chardonnay 96 as all the other somaclones. We suggest that during an early cell division a mutation occurred in locus $6 \mathrm{c} 10$ which replaced the $140 \mathrm{bp}$ allele by a 142 bp allele. The L2 cell layer of somaclone 21 originated from the diallelic mutated cell (114:142), whereas cells with the non mutated diallele (114:140) further multiplied giving the L1 cell layer of somaclone 21. This hypothesis is in accordance with the fact that the most frequently observed allelic size variation is the addition of one motif [14].

\section{Conclusion}

Regeneration via embryogenesis for Chardonnay 96 could result generally in a non chimeric plant and in an unchanged phenotype and would be well suited for gene transfer.

\section{Methods}

\section{Plant material}

Vitis vinifera cv. Chardonnay clone 96, was obtained from ENTAV (Etablissement National Technique pour l'Amélioration de la Viticulture, Le Grau du Roi, France), the national repository for registered grape clones in France. Forced adult plants were maintained in a growth chamber at $25 \pm 0.5^{\circ} \mathrm{C}, 70 \pm 10 \% \mathrm{RH}$ with a $16 \mathrm{~h}$ - photoperiod.

\section{Initiation of embryogenic calli from anthers}

Anthers were dissected and grown as described by Mauro et al. [15]. For long-term culture of embryogenic callus, subcultures were performed every three weeks on the MPM medium described by Perrin et al. [16]. All the cultures were maintained at $25 \pm 0.5^{\circ} \mathrm{C}, 70 \pm 10 \% \mathrm{RH}$ with a $16 \mathrm{~h}$ - photoperiod, except the very first step -the culture of detached anthers- which was performed in the dark.
For production of secondary embryos, primary embryos were cut off and transferred onto half strength Murashige and Skoog medium (MS medium) [17] supplemented with 20 g.l $\mathrm{l}^{-1}$ sucrose, $0.7 \%$ Bacto-agar, $2.5 \mu \mathrm{M}$ 2,4-dichlorophenoxyacetic acid (2,4-D) and $0.5 \mu \mathrm{M}$ 6-benzylaminopurine (BA; N6-benzyladenine). Incubation was done at $25 \pm 0.5^{\circ} \mathrm{C}$ in the dark, during 3 weeks. Then calli were subcultured every three weeks on MPM medium and maintained under the same conditions as previously described.

\section{Initiation of embryogenic calli from nodal explants}

Nodal explants were excised from plantlets grown in vitro and plated on half strength MS medium supplemented

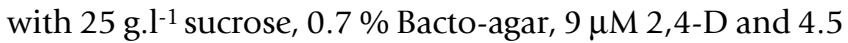
$\mu \mathrm{M}$ BA. Subculture was performed on half strength MS

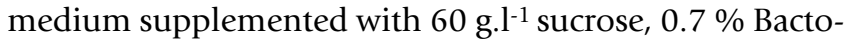
agar, $20 \mu \mathrm{M}$ indole-3-acetic acid (IAA), $10 \mu \mathrm{M}$ 2-naphtoxyacetic acid (NOA) and $1 \mu \mathrm{M}$ BA. Embryogenic calli were obtained after several transfers onto this last medium. For long-term culture of embryogenic callus, subcultures were performed every three weeks on the same medium. All the cultures were maintained at $25 \pm$ $0.5^{\circ} \mathrm{C}, 70 \pm 10 \% \mathrm{RH}$ with a $16 \mathrm{~h}$ - photoperiod, except the callus initiation which was performed in the dark.

\section{Regeneration and acclimatization of somaclones}

Embryos were carefully excised and transferred onto half-

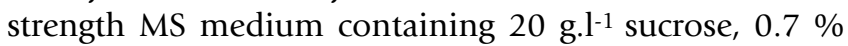
agar and $0.4 \mu \mathrm{M} \mathrm{BA}$. After two weeks at $25 \pm 0.5^{\circ} \mathrm{C}$ and 16 $\mathrm{h}$ light, the growing embryos were individually transferred into tubes containing half-strength MS medium without plant growth factor. Plantlets with rootlets were transferred to soil and allowed to acclimatize in a growth chamber for about three weeks before transfer to a greenhouse.

\section{Ampelographic observation}

Conformity of the different 3 years old somaclones were based on visual observation of leaf morphology and phyllotaxy compared to Chardonnay clone 96.

\section{Shoot organogenesis}

In vitro propagation of $V$. vinifera Chardonnay 96 was initiated on MS basal medium supplemented with $4.4 \mu \mathrm{M}$ BA, 30 g. $\mathrm{l}^{-1}$ sucrose and $0.7 \%$ Bacto agar. Meristematic bulks were initiated on IM medium of Mezzetti et al. [2] supplemented with $0.05 \mu \mathrm{M}$ NAA ( $\alpha$-naphtalene-acetic acid) and increasing concentrations of BA : $4.4 \mu \mathrm{M}$ for the first 30 days subculture, $8.8 \mu \mathrm{M}$ for the second subculture and finally $13.2 \mu \mathrm{M}$. At each transplantation, the apical dome was eliminated.

In order to induce shoot organogenesis, thin slices were cut from the inner part of the meristematic bulks and 
transferred onto IM medium containing $13.2 \mu \mathrm{M}$ BA. Growing shoots were transferred to rooting medium of Quoirin and Lepoivre [18] containing 4.9 $\mu \mathrm{M}$ indole-3butyric acid (IBA) and $5.7 \mu \mathrm{M}$ IAA [2]. Growing plantlets were further propagated on hormone free MS medium with half strength macroelements.

\section{DNA extraction}

Leaves were harvested from plants regenerated through somatic embryogenesis or shoot organogenesis: these plants were in vitro and greenhouse-grown somaclones and in vitro-grown clones from organogenesis. Leaves from greenhouse-grown plants of Chardonnay 96 mother clone were used as a control. Rootlets were taken from in vitro-grown plantlets. Wood tissue was obtained from the dormant canes after the bark and cambium were first scraped away. Berry skin, removed using a scalpel, was also analysed. About $80 \mathrm{mg}$ tissue was ground in liquid nitrogen using a grinder (Retsch MM200) and total DNA was extracted with the Qiagen Dneasy Plant mini-kit (Qiagen, Hilden, Germany) as described by the supplier.

\section{Amplification of microsatellites and polymorphism detection}

DNA was analysed using two pairs of primers flanking two different microsatellite regions: VMC6c10 and VMC $5 g 7$ (Vitis Microsatellites Consortium, Dr. Rosa Arroyo Garcia and Dr. Kirsten Wolff), respectively marked with the fluorophores HEX and FAM. Amplification reactions were performed in a total volume of $50 \mu \mathrm{l}$ with $10 \mathrm{ng}$ of template DNA, $0.35 \mu \mathrm{M}$ of forward primer labelled either with 6-FAM or HEX fluorophore, $0.35 \mu \mathrm{M}$ of non-labelled reverse primer, $200 \mu \mathrm{M}$ dNTP (Invitrogen), $1.5 \mathrm{mM}$ $\mathrm{MgCl}_{2}, 1 \mathrm{X}$ PCR Buffer and 0.2 unit Platinium ${ }^{\circledR}$ Taq DNA Polymerase (Invitrogen). The PCR was carried out using a GeneAmp ${ }^{\circledast}$ PCR System 2700 thermocycler (Applied Biosystems). The cycling program consisted of the following steps: 2 min at $94^{\circ} \mathrm{C}$ followed by 35 cycles of $40 \mathrm{~s}$ at $92^{\circ} \mathrm{C}$, $1 \mathrm{~min}$ at $57^{\circ} \mathrm{C}$ and $1 \mathrm{~min}$ at $72^{\circ} \mathrm{C}$ and a final extension step of $7 \mathrm{~min}$ at $72^{\circ} \mathrm{C}$. The amplification products were separated by capillary electrophoresis and detected with an ABI PRISM 310 Genetic Analyser (Applied Biosystem), using HD400-ROX as an internal size standard. The PCR fragments were detected with the GeneScan ${ }^{\mathrm{TM}}$ analysis software version 3.1 and the alleles were scored using the Genotyper $^{\mathrm{Tm}}$ DNA fragment analysis software version 2.5.2 (Applied Biosystems).

\section{Authors' contributions}

$\mathrm{CB}$ carried out the molecular studies, participated in the analyses of tissues and extract, and drafted the manuscript. FK and SF participated in the production of embryogenic calli from anthers. PM participated in the production of embryogenic calli from nodal explants. GM and DM partipated in the analyses of tissues. BW initiated shoot organogenesis and envisioned and supervised all the studies, as well as drafting the manuscript.

\section{Acknowledgements}

The authors are grateful to Dr. Rosa Arroyo Garcia and Dr. Kirsten Wolff for the VMC $6 \mathrm{cl} 0$ and VMC 5g7 primer sequences.

\section{References}

I. Martinelli L, Mandolino G: Transgenic Grapes (Vitis species). Biotechnology in Agriculture and Forestry 2003, 47:325-338.

2. Mezzetti B, Pandolfini T, Navacchi O, Landi L: Genetic transformation of Vitis vinifera via organogenesis. BMC Biotechnology 2002, 2:1-10.

3. Desperrier JM, Berger JL, Bessis R, Fournioux JC, Labroche C: Création clonale dirigée par embryogenèse somatique. Bulletin de I'O.I.V 2003, 76:87I-872.

4. Thompson NM, Olmo HP: Cytohistological studies of cytochimeric and tetraploid grapes. Amer J Bot 1963, 50:901-906.

5. Franks T, Botta R, Thomas MR: Chimerism in grapevines: implications for cultivar identity, ancestry and genetic improvement. Theor Appl Genet 2002, 104: 192-199.

6. Sefc KM, Lefort F, Grando MS, Scott K, Steinkellner H, Thomas MR: Microsatellite markers for grapevine: a state of the art. In Molecular Biology and Biotechnology of Grapevine Edited by: RoubelakisAngelakis KA. Kluwer Publishers, Amsterdam; 2001:433-463. ISBN 0-7923-6949-I

7. This $P$, Jung $A$, Boccacci $P$, Borrego J, Botta R, Costantini L, Crespan M, Dangl GS, Eisenheld C, Ferreira-Monteiro F, Grando S, Ibanez J, Lacombe T, Laucou, Magalhaes R, Meredith CP, Milani N, Peterlunger $E$, Regner F, Zulini L, Maul E: Development of a standard set of microsatellite reference alleles for identification of grape cultivars. Theor Appl Genet 2004, 109: I448- I458.

8. Merdinoglu D, Butterlin G, Bevilacqua L, Chiquet V, Adam-Blondon $A F$, Decroocq S: Development and characterization of a large set of microsatellite markers in grapevine (Vitis vinifera) suitable for multiplex PCR. Molecular Breeding 2005 in press.

9. Riaz S, Garrison KE, Dangl GS, Boursiquot JM, Meredith CP: Genetic divergence and chimerism within ancient asexually propagated wine grape cultivars. J Amer Soc Hort Sci 2002, I27:508-5।4.

10. Hocquigny S, Pelsy F, Dumas V, Kindt S, Heloir MC, Merdinoglu D: Diversification within grapevine cultivars goes through chimeric states. Genome 2004, 47:579-589.

II. Bertsch C, Kieffer F, Triouleyre C, Butterlin G, Merdinoglu D, Walter $B$ : Molecular profiling of Vitis vinifera Chardonnay obtained by somatic embryogenesis. J Int Sci Vigne Vin 2003, 34:223-227.

12. Morrison J: Bud development in Vitis vinifera L. Bot Gaz 199I, 152:304-315.

13. Henry RJ: Molecular and biochemical characterization of somaclonal variation. In Somaclonal variation and induced mutations in crop improvement Edited by: Jain SM, Brar DS, Ahloowalia BS. Kluwer Academic Publishers, Dordrecht, Boston, London; 1998:485-499.

14. Hocquigny S: La diversité génétique intra-variétale chez la vigne: caractérisation et origines. In PhD thesis Université Louis Pasteur, Strasbourg; 2003:138.

15. Mauro M, Nef C, Fallot J: Stimulation of somatic embryogenesis and plant regeneration from anther culture of Vitis vinifera cv. Cabernet-Sauvignon. Plant Cell Reports 1986, 5:377-380.

16. Perrin M, Martin D, Joly D, Demangeat G, This P, Masson JE: Medium-dependent response of grapevine somatic embryogenic cells. Plant Science 2001, 161:107-116.

17. Murashige T, Skoog F: A revised medium for rapid growth and bioassays with tobacco tissue cultures. Physiol Plant 1962, 1 5:473-497.

18. Quoirin M, Lepoivre P: Improved media from in vitro culture of Prunus spp. Acta Horticulturae 1997, 78:437-442. 